\title{
Attenuation of groundwater pollution by bank filtration
}

\author{
K.M. Hiscock ${ }^{\mathrm{a}, *}$, T. Grischek ${ }^{\mathrm{b}}$ \\ ${ }^{\text {a }}$ School of Environmental Sciences, University of East Anglia, Norwich NR4 7TJ, UK \\ ${ }^{\mathrm{b}}$ Institute of Water Chemistry, Dresden University of Technology, Mommsenstr. 13, D-01062 Dresden, Germany
}

Received 23 October 2001

\begin{abstract}
Bank filtration, either natural or induced through the river bed by pumping from a system of connected lateral or vertical wells, provides a means of obtaining public water supplies. The success of such schemes is dependent on the microbial activity and chemical transformations that are commonly enhanced in the colmation layer within the river bed compared to those that take place in surface or ground waters. The actual biogeochemical interactions that sustain the quality of the pumped bank filtrate depend on numerous factors including aquifer mineralogy, shape of the aquifer, oxygen and nitrate concentrations in the surface water, types of organic matter in the surface and ground water environments, and land use in the local catchment area. This paper provides an introduction to a series of nine papers contained in this Special Issue that highlight these factors and finishes with a list of recommendations for co-ordinated research into attenuation of groundwater pollution by bank filtration. (C) 2002 Elsevier Science B.V. All rights reserved.
\end{abstract}

Keywords: Bank filtration; Colmation layer; Alluvial aquifer; Organic contaminents; Biodegradation

\section{Introduction}

This Special Issue has its origins in a two-day workshop on the Attenuation of Groundwater Pollution by Bank Filtration held at the Dresden University of Technology, Germany, in June 2000 (website www.bankfiltration.org). The workshop was funded by the European Science Foundation under its Groundwater Pollution (GPoll) Programme and attracted 23 participants from 12 countries within Europe and the United States. The workshop was organised around five sessions (determination of infiltration zones and velocities, the river bed as an attenuation barrier for groundwater pollution, fate of

\footnotetext{
* Corresponding author. Tel.: +44-1603-593104; fax: +441603-507719.

E-mail address: k.hiscock@uea.ac.uk (K.M. Hiscock).
}

synthetic organic compounds during bank filtration, elimination of microbial pathogens during bank filtration, and bank filtration as an effective pretreatment for water production) and representative papers under these session themes are presented in this Special Issue.

Additional relevant information is currently available from the extended abstracts in the proceedings of the International Riverbank Filtration Conference held in November 1999 in Louisville, Kentucky, United States and from a NATO Advanced Research Workshop on Riverbank Filtration on Understanding Contaminant Biogeochemistry and Pathogen Removal held in September 2001 in Tihany, Hungary. Proceedings from an International Riverbank Filtration Conference held in November 2000 in Düsseldorf, Germany (Jülich and Schubert, 2000) include full papers and give an overview of research 
in the field of bank filtration in Germany and The Netherlands. These recent workshops and conferences on bank filtration underline the importance of bank filtration as a valuable water resource. Future publications include the full text of papers from the NATO Workshop (Ray, 2002) and a forthcoming compendium of papers on bank filtration (Ray and Linsky, 2002).

Complementary special issues that consider hydrological, ecological and modelling aspects of the inverse situation of the role of groundwater discharge in maintaining river flows are presented by Sear and Armitage (1999), Hiscock et al. (2002) and Younger (1995).

In many countries of the world, alluvial aquifers hydraulically connected to a water course are preferred sites for drinking water production given the relative ease of shallow groundwater exploitation, the generally high production capacity and the proximity to demand areas (Doussan et al., 1997). Although proximity to a river can ensure significantly higher recharge and pumping rates, water quality problems may be encountered during exploitation of river bank well-fields (Bertin and Bourg, 1994). Even with these problems, groundwater derived from infiltrating river water provides $50 \%$ of potable supplies in the Slovak Republic, $45 \%$ in Hungary, $16 \%$ in Germany and $5 \%$ in The Netherlands. In Germany, the City of Berlin depends $75 \%$ on bank filtration while Düsseldorf, situated on the Rhine, has been using river bank filtration since 1870 , with bank filtration the most important source for public water supply in this densely populated and industrialised region (Schubert, 2002).

In the United States, the water supply industry has adopted the broadly defined regulatory concept of 'groundwater under the direct influence' (GWUDI) of surface water (variably defined and implemented in response to local conditions by each State, Tribe or other regulatory agent). Groundwater sources in this category are considered at risk of being contaminated with surface water-borne pathogens (specifically disinfection-resistant pathogenic protozoa such as Cryptosporidium). Under the draft Proposed Long Term 2 Enhanced Surface Water Treatment Rule, the US Environmental Protection Agency (EPA) is considering awarding additional Cryptosporidium treatment credit for systems using bank filtration that meets certain design criteria (which could include defined separation distances between river and well) (US Environmental Protection Agency, 2001). Future, increased exploitation of water from alluvial aquifers along river banks is expected in the US given the rise in demand for drinking water, the ease of abstraction and the positive effects of bank filtration on the quality of the infiltrating surface water (Solley et al., 1998).

\section{Hydraulic controls on bank filtration}

River bank filtration can occur under natural conditions or be induced by lowering the groundwater table below the surface water level by abstraction from adjacent boreholes. Fig. 1 shows the typical flow conditions associated with different types of bank filtration schemes. For the quantitative and qualitative management of bank filtration systems, the catchment zones, infiltration zones, mixing proportions in the pumped raw water, flow paths and flow velocities of the bank filtrate need to be known. Flow conditions during bank filtration are commonly described using interpretations of water level measurements and hydrogeological modelling. An important factor is the formation of the colmation layer within the river bed that has a reduced hydraulic conductivity due to clogging from the input and precipitation of sediment particles, micro-organisms and colloids, precipitation of iron and manganese oxy-hydroxides and calcium carbonates as well as gas bubbles. Schubert (2002) reports that the permeability of clogged areas varies with the dynamic hydrology and cannot be regarded as constant. The hydraulic conductivity of the river bed is therefore a principal factor determining the volume of bank filtrate.

During floods having sufficient hydraulic transport energy, the river bed can be reworked and the colmation layer eroded. Flooding is expected to destabilise the river bed, to reduce the filter efficiency of the river bank and potentially endanger the operation of water supply facilities. In general, a higher portion of infiltrated water in the pumped raw water has to be expected due to the removal of the clogging layer and the greater hydraulic gradient from the river to the wells. In a study at a site on the oligotrophic River Enns in Austria, and focusing on the first metre of the flowpath, Wett et al. (2002) found that, immediately after flooding, the portion of 

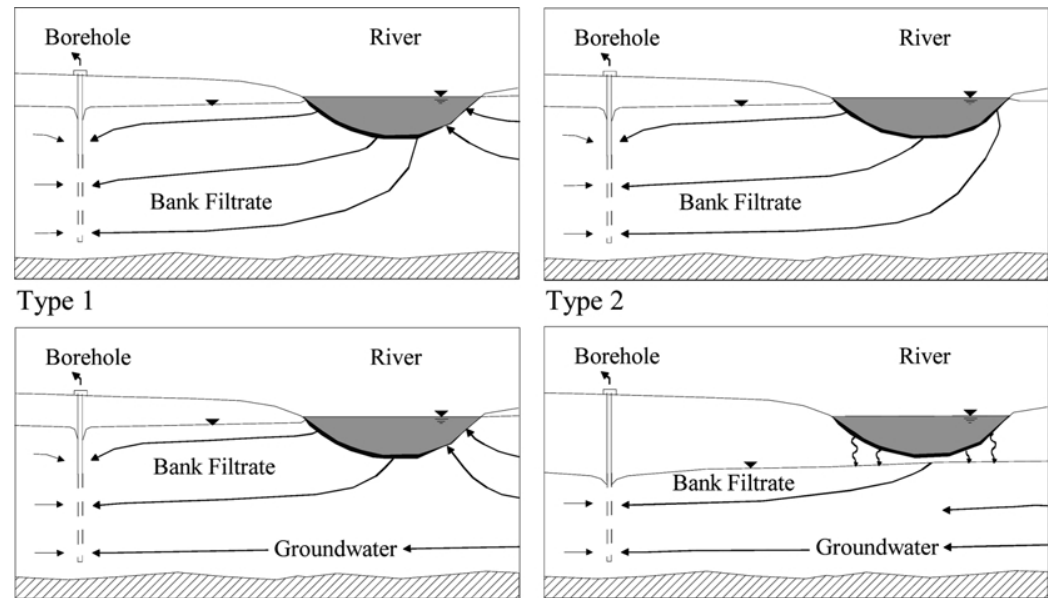

Type 2

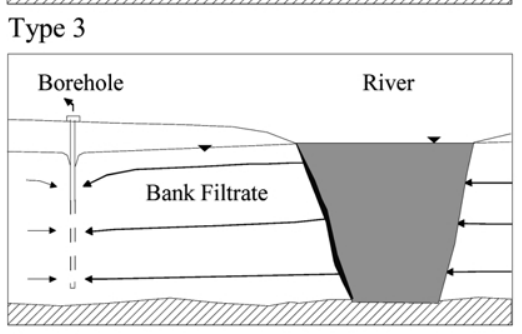

Type 5

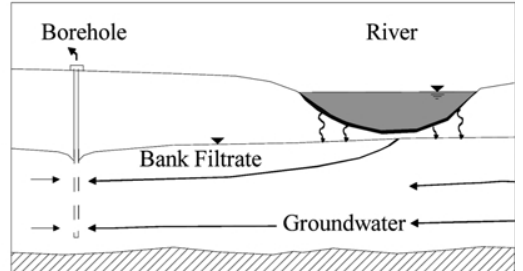

Type 4

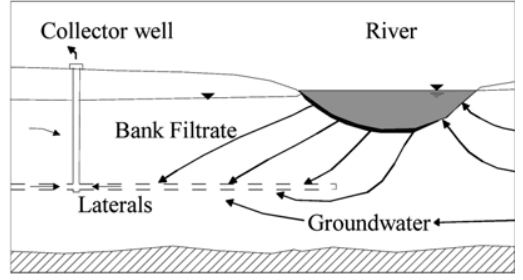

Type 6

Fig. 1. Schematic representation of types of flow conditions at bank filtration sites. The majority of river bank filtration schemes are of Type 1. Groundwater flow beneath the river (Types 3, 4 and 6) is typically neglected at most sites. The formation of unsaturated conditions beneath the river occurs if groundwater abstraction rates are not adapted to the hydraulic conductivity of the river bed or if the hydraulic conductivity of the river bed material becomes clogged due to surface water pollution inputs (Type 4). At some sites, the river bed cuts into the confining layer (Type 5). Collector wells are used with laterals at different depths, of different lengths and directions. Type 6 gives only one example with a lateral towards the river.

infiltrated river water in an abstraction well decreased significantly despite a constant hydraulic conductivity for the river bed. In this case, the increase in the groundwater table as a result of rainfall recharge and the rising stream flood level resulted in a reduced hydraulic slope and seepage rate by about $50 \%$ of the mean value. These findings highlight the significant influence of sitespecific conditions in affecting groundwater flow and transport processes at riverbank filtration sites.

Numerical modelling can achieve further insight into infiltration flow patterns where detailed hydraulic head and tracer test data are available. Ray et al. (2002) adopt such an approach to demonstrate the risk of contamination from surface water at a site on the River Illinois for different combinations of transport parameters. The model results interpreted with pesticide monitoring data showed that even during a flood, the risk of contamination from nitrate and atrazine is low for a small capacity $\left(2.7 \times 10^{3} \mathrm{~m}^{3}\right.$ day $\left.^{-1}\right)$ vertical bank filtration well but for a medium capacity (7.6$15.1 \times 10^{3} \mathrm{~m}^{3} \mathrm{day}^{-1}$ ) collector well the potential exists for a portion of the surface water contaminants to breakthrough during flood periods.

\section{Attenuation of contaminants by bank filtration}

Fig. 2 shows schematically the attenuation processes that are known from various bank filtration sites. Compared with surface water abstraction, bank filtration with its effective natural attenuation processes has the following advantages: elimination of suspended solids, particles, biodegradable compounds, bacteria, viruses and parasites; part elimination of adsorbable compounds; and the equilibration of temperature changes and concentrations of dissolved constituents in the bank 


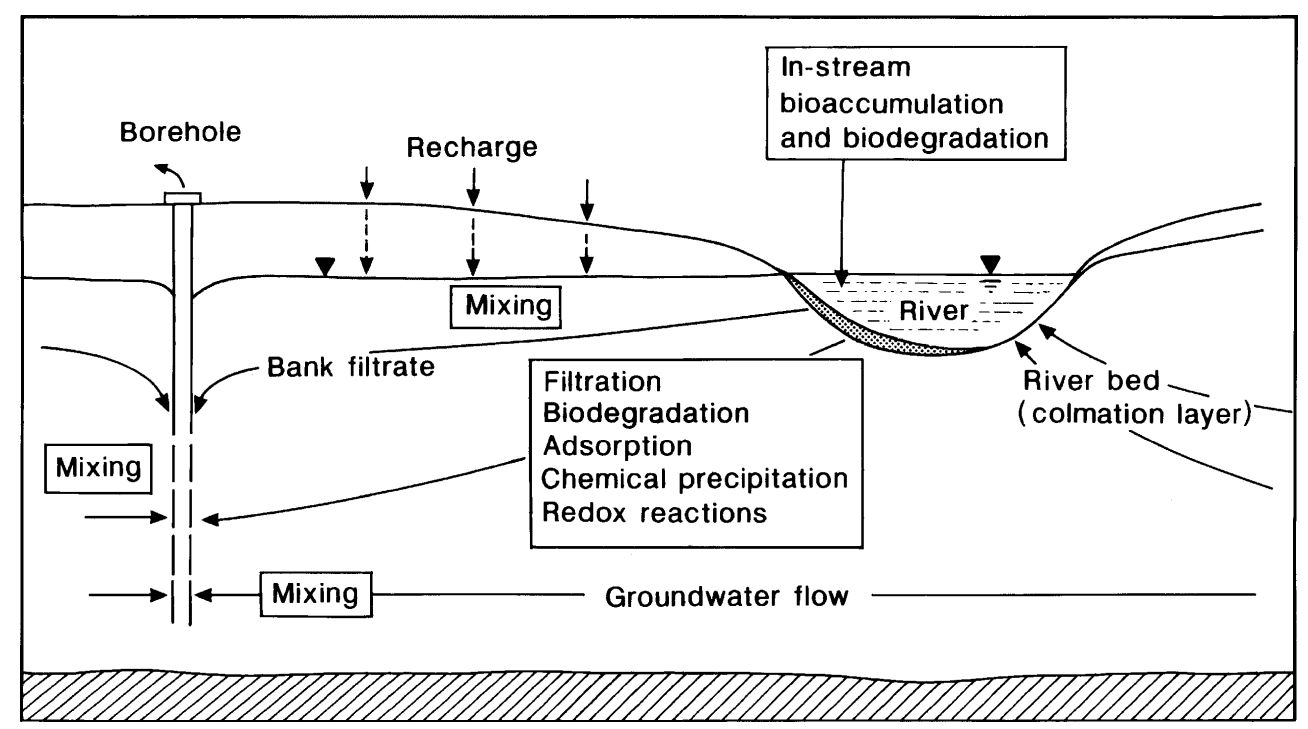

Fig. 2. Schematic diagram of processes affecting water quality during bank filtration. The natural attenuation of the bank filtrate is strongly dependent on site-specific hydrogeological and hydrochemical conditions.

filtrate. Undesirable effects of bank filtration on water quality can include increases in hardness, ammonium and dissolved iron and manganese concentrations and the formation of hydrogen sulphide and other malodorous sulphur compounds as a result of changing redox conditions.

The beneficial attenuation processes result mainly from mixing, biodegradation and sorption processes within two main zones: the biologically active colmation layer, where intensive degradation and adsorption processes occur within a short residence time; and along the main flowpath between the river and abstraction borehole where degradation rates and sorption capacities are lower and mixing processes greater. Travel times based on measurements of specific conductance ranged from approximately $20 \mathrm{~h}$ to 3 months at the site of a bank filtration scheme in southwest Ohio (Sheets et al., 2002) with shorter and more consistent travel times obtained under conditions of continuous pumping.

Diffuse sources of contamination in catchment runoff, especially from agricultural activities, can adversely affect river water quality and therefore bank filtrate. The study by Grischek et al. (1998) demonstrated the potential for denitrification at a sand and gravel aquifer site on the River Elbe where both dissolved and solid organic carbon within the aquifer acted as electron donors.
Verstraeten et al. (2002) report changes in concentrations of triazine and acetamide herbicides at a well-field on the River Platte in Nebraska and show that parent compounds were reduced by $76 \%$ of the river water value (with a third of this due to bank filtration) but that increases in concentrations of specific metabolite compounds were identified after bank filtration and ozonation treatment.

A further hazard relating to high loads of nutrient runoff from agricultural catchments is the occurrence of toxic cyanobacteria (blue-green algae) such as microcystin. Dillon et al. (2002) report the occurrence of cyanobacterial blooms in recent years in the MurrayDarling river basin of South Eastern Australia and provide evidence for adsorption and biodegradation of microcystin in porous media. In this area, and under the correct conditions that are partly determined by groundwater salinity, bank filtration may be a viable water treatment option for smaller water supply schemes in arid or semi-arid areas for the removal of algal toxins and reducing turbidity.

Polar organic molecules are an increasingly problematic class of contaminants for bank filtration schemes and include several pharmaceutically active compounds (PhACs) that are discharged almost unchanged from municipal sewage treatment plants. Heberer (2002) reports monitoring studies carried out in Berlin where PhACs such as clofibric acid (a blood 
lipid regulator used in human medical care), diclofenac and ibuprofen were detected at individual concentrations of up to several $\mu \mathrm{g} \mathrm{l^{-1 }}$ in groundwater samples from aquifers near to contaminated water courses. It is therefore apparent that several drug residues are not eliminated during recharge through the subsoil (Heberer, 2002).

\section{Modelling of bank filtration processes}

The mathematical description of contaminant behaviour during bank filtration is often simulated using mass transport modelling based on groundwater flow models. An example of the type of insight that can be gained is presented by Kim and Corapcioglu (2002) who developed a kinetic model to simulate contaminant transport during bank filtration in the presence of dissolved organic matter and bacteria. The model equations are solved numerically with a fully implicit finite difference method and the results show that contaminant mobility, with particular reference to hydrophobic organic compounds, can potentially increase in bank filtration due to the presence of dissolved organic matter and bacteria.

In practice, often the key question for the reliability of modelling approaches is the accurate determination of the necessary input parameters for the description of dispersion, diffusion, biodegradation, sorption, dissolution and precipitation processes. A significant challenge is the translation of the results of degradation kinetics obtained from batch or testfilter laboratory experiments. The results often depend on the chosen experimental method and differ from the changing microbiological conditions that actually exist in the river bed and along a groundwater flowpath. An example of column and testfilter laboratory experiments to simulate adsorption and biological degradation processes of aromatic amines in river bank filtration is presented by Worch et al. (2002). The value of this approach is that it is possible to derive a prognosis of the behaviour of such organic compounds during river bank filtration and to prioritise the substances with regard to drinking water quality. Biodegradation of some aromatic amines is relatively slow and adsorption onto sandy aquifer material is weak such that these synthetic organic chemicals cannot be assumed to be excluded in bank filtration production wells.

\section{Conclusions and further research directions}

Over a century of experience exists in the operation and maintenance of bank filtration schemes in Europe but current understanding of bank filtration schemes is primarily based on empirical knowledge. There are no common guidelines on conditions necessary for the optimisation and protection of bank filtration schemes. Although knowledge exists for site-specific problems of water supply related to different hydrogeological and hydrochemical settings, there is a lack of comparative data interpretation, systematic description and conclusions. Recognising the historical importance of bank filtration as contributing significantly to regional water resources in many areas of Europe and elsewhere the following conclusions were agreed at the Dresden workshop to improve understanding of bank filtration schemes:

- Understanding the aquifer conditions and hydraulic controls imposed by pumping regimes is a prerequisite in determining the pattern and rate of contaminant migration and the position of chemically reducing zones.

- Clogging of river bed sediments can be both beneficial in terms of promoting the biodegradation of contaminants but also undesirable in reducing the hydraulic conductivity of the infiltration zone.

- Chemical and natural radioactive tracers provide a useful research tool for understanding the biogeochemical degradation of river-derived contaminants within the zone of infiltration.

- Redox processes are important in determining the hydrogeochemical environment that can benefit the breakdown of natural and synthetic organic compounds but can also introduce problems of high iron and manganese concentrations.

- Understanding the capacity of river bed material to retard problematic polar compounds, pharmaceuticals and endocrine disrupters such as DDT metabolites is essential for the longer term protection of bank filtration schemes.

- Pathogenic bacteria, viruses and Cryptosporidium 
can be effectively reduced or eliminated by bank filtration but for reasons that are not entirely understood at this time.

- Management of bank filtration schemes should be incorporated into wider catchment planning in order to limit potentially polluting activities in the groundwater recharge area and also to balance river infiltration losses with the ecological needs of the river.

In order to formulate guidelines on conditions necessary for the optimisation and protection of bank filtration schemes, further intensive research is required to quantify chemical reaction rates and microbial degradation, especially in the river bed, and to include the effects of $\mathrm{pH}$ and redox controls, the behaviour and importance of biofilms, the fate of micropollutants and persistent compounds such as PhACs, and the mobility, adsorption and inactivation of viruses, pathogens and protozoa. The development of risk quantification methods, for example identification of relevant compounds and metabolites, and appropriate alarm systems are also required to ensure the long-term sustainability of bank filtration schemes.

\section{Acknowledgments}

The authors are grateful to the European Science Foundation for financial assistance under its GPoll Programme in supporting the international workshop held at the Dresden University of Technology (TUD) in June 2000. Dagmar Schoenheinz and staff at the Institute of Water Chemistry at TUD are thanked for their expert organisation of the workshop sessions. We are greatly indebted to the many referees who provided helpful comments on earlier drafts of the papers contained in this Special Issue and also to Dr Philip Berger of the US Environmental Protection Agency for his comments on a draft of this introductory paper.

\section{References}

Bertin, C., Bourg, A.C.M., 1994. Radon-222 and chloride as natural tracers of the infiltration of river water into an alluvial aquifer in which there is significant river/groundwater mixing. Environ. Sci. Technol. 28, 794-798.
Dillon, P.J., Miller, M., Fallowfield, H., Hutson, J., 2002. The potential of river bank filtration for drinking water supplies in relation to microcystin removal in brackish aquifers. J. Hydrol..

Doussan, C., Poitevin, G., Ledoux, E., Detay, M., 1997. River bank filtration: modelling of the changes in water chemistry with emphasis on nitrogen species. J. Contam. Hydrol. 25, 129-156.

Grischek, T., Hiscock, K.M., Metschies, T., Dennis, P.F., Nestler, W., 1998. Factors affecting denitrification during infiltration of river water into a sand aquifer in Saxony, eastern Germany. Water Res. 32, 450-460.

Heberer, T., 2002. Tracking persistent pharmaceutical residues from municipal sewage to drinking water. J. Hydrol..

Hiscock, K.M., Rivett, M.O., Davison, R.M. (Eds.), 2002. Sustainable Groundwater Development, vol. 193. Geological Society, London, 352, pp. Special publications.

Jülich, W., Schubert, J. (Eds.), 2000. Proceedings of the International Riverbank Filtration Conference, 2-4 November 2000, Düsseldorf, Germany, IAWR Rheinthemen, vol. 4., 309 pp.

Kim, S.-B., Corapcioglu, M.Y., 2002. Contaminant transport in river bank filtration in the presence of dissolved organic matter and bacteria: a kinetic approach. J. Hydrol..

Ray, C., Linsky, R. (Eds.), 2002. Bank Filtration: Improving Source Water Quality, Kluwer, The Netherlands, in press.

Ray, C., 2002. NATO ARW Riverbank Filtration: Understanding Contaminant Biogeochemistry and Pathogen Removal, Kluwer, The Netherlands, in press.

Ray, C., Soong, T.W., Lian, Y., Roadcap, G.S., 2002. Effect of flood-induced chemical load on filtrate quality at bank filtration sites. J. Hydrol..

Schubert, J., 2002. Hydraulic aspects of river bank filtration-field studies. J. Hydrol..

Sear, D.A., Armitage, P.D., 1999. Groundwater dominated rivers. Spec. Issue, Hydrol. Process. 13 (4).

Sheets, R.A., Darner, R.A., Whitteberry, B.L., 2002. Lag times of bank filtration at a well field, Cincinnati, OH, USA. J. Hydrol.

Solley, W.B., Pierce, R.R., Perlman, H.A., 1998. Estimated use of water in the United States in 1995. US Geol. Circ. 1200.

US Environmental Protection Agency, 2001. National Primary Drinking Water Regulations: Long Term 2 Enhanced Surface Water Treatment Rule. Environmental Protection Agency, 40 CFR Parts 9, 141 and 142, pp. 217-231.

Verstraeten, I.M., Thurman, E.M., Lindsey, M.E., Lee, E.C., Smith, R.D., 2002. Changes in concentrations of triazine and acetamide herbicides by bank filtration, ozonation, and chlorination in a public water supply. J. Hydrol.

Wett, B., Jarosch, H., Ingerle, K., 2002. Flood induced infiltration affecting a bank filtrate well at the River Enns, Austria. J. Hydrol..

Worch, E., Grischek, T., Börnick, H., Eppinger, P., 2002. Laboratory tests for simulating attenuation processes of aromatic amines in river bank filtration. J. Hydrol.

Younger, P.L. (Ed.), 1995. Modelling river-aquifer interactions. British Hydrological Society Occasional Paper No. 6, Wallingford, $160 \mathrm{pp}$. 